\title{
ANALISIS PENGARUH TAX AVOIDANCE TERHADAP COST OF DEBT PADA PERUSAHAAN MANUFAKTUR YANG TERDAFTAR DI BEI SELAMA PERIODE 2010-2014
}

\author{
Janice Ekasanti Santosa \\ Heni Kurniawan \\ Program Studi Akuntansi Fakultas Ekonomi Universitas Atma Jaya Yogyakarta \\ Jalan Babarsari 43-44, Yogyakarta
}

\begin{abstract}
ABSTRAK
Cost of debt yang ditanggung perusahaan ditetapkan oleh kreditor berdasarkan cara manajemen mengelola perusahaan. Pengelolaan yang efektif dan efisien terkait dengan cara manajemen meningkatkan pendapatan dan menekan beban untuk memperoleh laba yang maksimal. Salah satu beban yang harus dikelola ialah beban pajak. Penghematan pajak yang masih memenuhi ketentuan perpajakan dikenal dengan istilah tax avoidance. Penelitian ini bertujuan untuk menguji kembali pengaruh tax avoidance terhadap cost of debt pada perusahaan manufaktur yang terdaftar di Bursa Efek Indonesia (BEI) periode 2010-2014.

Penelitian ini menggunakan data arsip sekunder yang diperoleh dari laporan keuangan perusahaan manufaktur yang terdaftar di BEI selama periode 2010-2014. Sampel dipilih menggunakan metode purposive sampling dan didapatkan sampel sebanyak 49 perusahaan dengan periode observasi 5 tahun sehingga total data yang diobservasi adalah sebesar 245 data. Pengujian hipotesis dilakukan dengan regresi linier sederhana.

Berdasarkan hasil analisis, diperoleh hasil bahwa tax avoidance berpengaruh positif terhadap cost of debt pada perusahaan manufaktur yang terdaftar di Bursa Efek Indonesia (BEI) periode 2010-2014. Kreditor menganggap tax avoidance sebagai praktik yang mengandung risiko sehingga meningkatkan cost of debt.
\end{abstract}

Kata kunci: cost of debt, tax avoidance, perusahaan manufaktur terdaftar di BEI periode 2010-2014.

\section{PENDAHULUAN}

Dalam rangka mempertahankan dan mengembangkan bisnisnya, perusahaan juga membutuhkan sumber pendanaan eksternal. Salah satu sumber pendanaan eksternal yang biasa dilakukan adalah dengan menerbitkan surat utang yang nantinya akan dibeli oleh kreditor. Dengan membeli surat utang, kreditor akan mendapatkan imbal hasil berupa bunga. Bagi perusahaan yang berutang, bunga tersebut merupakan pengembalian yang harus diberikan perusahaan pada kreditor. Tingkat pengembalian yang diberikan perusahaan inilah yang akan menjadi cost of debt (biaya utang) bagi perusahaan (Marcelliana, 2014).

Selain mendapatkan imbal hasil (return) berupa bunga, kreditor juga menanggung risiko dari pilihan investasinya. Salah satu jenis risiko yang ditanggung kreditor adalah risiko perusahaan, yaitu risiko terkait karakteristik perusahaan dan cara manajemen mengelola perusahaan. Return dan risiko merupakan trade-off. Semakin besar kreditor menilai risiko yang dimiliki suatu perusahaan, semakin besar pula bunga yang akan dibebankan pada perusahaan tersebut. Hal ini berarti cost of debt dipengaruhi oleh risiko perusahaan. 
Pengelolaan perusahaan yang efektif dan efisien biasanya dikaitkan dengan perolehan laba yang optimal. Untuk memperolehnya, perusahaan dituntut untuk meningkatkan pendapatan dan menekan beban pada tingkat minimum. Salah satu beban yang harus dikelola oleh perusahaan ialah beban pajak. Menurut Suandy (2011), upaya penghematan pajak dapat dilakukan dengan berbagai cara, baik yang lawful (masih memenuhi ketentuan perpajakan) maupun yang unlawful (melanggar peraturan perpajakan). Penghematan pajak sebagai upaya perusahaan untuk memperoleh laba yang maksimal biasanya dilakukan dengan cara yang lawful atau sering disebut tax avoidance (penghindaran pajak). Secara hukum, tax avoidance tidak dilarang, namun sering mendapat sorotan yang kurang baik dari kantor pajak karena dianggap memiliki konotasi negatif dan menunjukkan perilaku ketidakpatuhan.

Konotasi negatif ini akan membuat kreditor memandang praktik tax avoidance yang dilakukan perusahaan sebagai tindakan yang mengandung risiko. Masri dan Martani (2012) menyatakan bahwa pandangan kreditor ini antara lain disebabkan oleh pemerintah menerbitkan UU nomor 28 tahun 2007 (sekarang UU nomor 16 tahun 2009) tentang Ketentuan Umum dan Tata Cara Perpajakan (KUP), melakukan reformasi perpajakan, dan meningkatkan pemberantasan korupsi. Pandangan ini membuat kreditor cenderung membebankan bunga yang lebih besar. Maka, dapat disimpulkan bahwa semakin tinggi tax avoidance yang dilakukan perusahaan, semakin besar cost of debt yang ditanggungnya.

Penelitian mengenai pengaruh tax avoidance terhadap cost of debt telah beberapa kali dilakukan. Penelitian ini pernah dilakukan oleh Masri dan Martani (2012). Hasilnya menunjukkan bahwa tax avoidance berpengaruh positif terhadap cost of debt. Penelitian yang sama juga dilakukan oleh Marcelliana (2014) dan menunjukkan hasil yang konsisten dengan penelitian Masri dan Martani (2012). Hasil yang berbeda ditunjukkan oleh penelitian yang dilakukan Novianti (2014) yang menunjukkan bahwa tax avoidance tidak berpengaruh positif terhadap cost of debt. Selain itu, penelitian ini juga pernah dilakukan oleh Erniawati (2014) yang menunjukkan bahwa tax avoidance berpengaruh negatif terhadap cost of debt.

Hasil penelitian terdahulu yang tidak konsisten memotivasi peneliti untuk menguji kembali pengaruh tax avoidance terhadap cost of debt. Penelitian akan dilakukan pada perusahaan manufaktur yang terdaftar di Bursa Efek Indonesia (BEI) selama periode 20102014. Perusahaan manufaktur dipilih dengan mempertimbangkan kecukupan data yang memiliki kesamaan karakteristik. Periode pengamatan dipilih selama periode 2010-2014 karena adanya perubahan tarif pajak pada tahun 2008-2010 yang memengaruhi langsung penghitungan beban pajak bagi perusahaan manufaktur. Oleh karena itu, dapat disimpulkan bahwa tarif pajak untuk perusahaan manufaktur baru stabil pada tahun 2010 dan masih berlaku sampai sekarang.

Berdasarkan latar belakang tersebut, rumusan masalah penelitian ini adalah apakah tax avoidance memiliki pengaruh positif terhadap cost of debt pada perusahaan manufaktur yang terdaftar di BEI selama periode 2010-2014. Penelitian ini bertujuan untuk menguji kembali pengaruh tax avoidance terhadap cost of debt pada perusahaan manufaktur yang terdaftar di BEI selama periode 2010-2014. Manfaat penelitian ini adalah sebagai berikut:

1. Kontribusi Praktik

Penelitian ini diharapkan dapat memberikan pengetahuan tentang cara mengukur adanya praktik tax avoidance dan pengetahuan bahwa tax avoidance dipandang sebagai risiko investasi sehingga dapat membantu para manajer perusahaan untuk 
mengambil keputusan ataupun mempertimbangkan kembali keputusan terkait tax avoidance dan sumber pendanaan dari utang.

2. Kontribusi Kebijakan

Penelitian ini diharapkan dapat membantu dewan komisaris untuk membuat kebijakan yang tepat terkait dengan utang dan praktik-praktik tax avoidance sehingga perusahaan dapat mengelola perusahaan secara efektif dan efisien (meminimalkan cost of debt sekaligus beban pajak).

\section{DASAR TEORI DAN PENGEMBANGAN HIPOTESIS}

\section{Signalling Theory}

Asumsi utama signalling theory (teori sinyal) adalah manajemen mempunyai informasi yang akurat tentang nilai perusahaan yang tidak diketahui oleh investor luar dan manajemen adalah orang yang selalu berusaha memaksimalkan insentif yang diharapkan (Muwardi, 2010). Keinginan manajemen untuk memaksimalkan insentif tersebut membuatnya tidak secara penuh menyampaikan semua informasi yang dimiliki karena mungkin dapat mempengaruhi nilai perusahaan. Hal ini menyebabkan terjadinya asymmetric information yang dapat menyulitkan investor untuk menilai kualitas perusahaan. Akibatnya, investor secara rata-rata akan memberikan penilaian yang kurang baik terhadap semua perusahaan. Kecenderungan ini disebut pooling equilibrium (Arifin dalam Muwardi, 2010) yang tentu sangat merugikan bagi perusahaan berkualitas baik. Untuk mengatasi masalah ini, perusahaan memberikan suatu informasi ke pasar yang secara umum dapat direspon sebagai sebuah sinyal. Setelah menerima informasi tersebut, investor akan menganalisisnya sebagai good news atau bad news dan hasilnya menjadi dasar untuk mengambil keputusan investasi.

\section{Return dan Risiko}

Investasi adalah penundaan konsumsi sekarang untuk dimasukkan ke aktiva produktif selama waktu tertentu (Hartono, 2014). Ketika menginvestasikan dananya pada suatu atau beberapa aset, investor mengharapkan sejumlah return tertentu yang disebut dengan return ekspektasian yang dalam kenyataannya tidak selalu sama dengan return realisasian. Menurut Hartono (2014), penyimpangan dari outcome yang diterima dengan ekspektasinya ini disebut risiko. Terdapat dua jenis risiko, yaitu risiko sistematis yang terkait dengan pasar modal tempat suatu sekuritas diperjualbelikan dan risiko perusahaan yang terkait dengan perusahaan yang menerbitkan suatu sekuritas. Return dan risiko merupakan dua hal yang tidak terpisahkan, karena pertimbangan suatu investasi merupakan trade-off dari kedua faktor ini (Hartono, 2014). Return dan risiko ini memiliki hubungan yang positif.

\section{Cost of Debt}

Dalam rangka mempertahankan dan mengembangkan bisnisnya, perusahaan juga membutuhkan sumber pendanaan eksternal dari kreditor dalam bentuk utang. Return bagi kreditor ialah bunga. Bagi perusahaan yang berutang, bunga merupakan pengembalian yang harus diberikan perusahaan pada kreditor sampai utang tersebut dapat dilunasi. Tingkat pengembalian inilah yang akan menjadi cost of debt bagi perusahaan (Marcelliana, 2014). Cost of debt diukur dengan membagi beban bunga yang dibayarkan oleh perusahaan dalam periode satu tahun dibagi dengan jumlah rata-rata pinjaman jangka panjang dan pendek yang berbunga selama tahun tersebut (Pittman dan Fortin dalam Masri dan Martani, 2012). 
Salah satu jenis risiko ialah risiko perusahaan, yaitu resiko terkait dengan perusahaan yang menerbitkan suatu sekuritas, misalnya karakteristik dan cara manajemen mengelola perusahaan. Return dan risiko merupakan trade-off. Maka semakin besar kreditor menilai risiko perusahaan, semakin besar pula bunga yang akan dibebankan kreditor pada perusahaan tersebut. Hal ini menunjukkan bahwa cost of debt akan sangat bergantung pada karakteristik perusahaan dan cara manajemen mengelola perusahaan. Pengelolaan perusahaan yang efektif dan efisien biasanya dikaitkan dengan perolehan laba yang optimal. Untuk memperoleh laba yang optimal, perusahaan dituntut untuk meningkatkan pendapatan dan menekan beban pada tingkat minimum. Salah satu beban yang penting untuk dikelola oleh perusahaan ialah beban pajak yang harus dibayarkan perusahaan sesuai dengan peraturan yang berlaku.

\section{Pajak}

Soemitro dalam Suandy (2011) mendefinisikan pajak sebagai iuran rakyat kepada kas negara yang berdasarkan undang-undang (yang dapat dipaksakan) dengan tidak mendapat jasa imbal (kontraprestasi), yang langsung dapat ditunjukkan dan yang digunakan untuk membayar pengeluaran umum. Salah satu jenis pajak adalah Pajak Penghasilan (PPh). Subjek $\mathrm{PPh}$ meliputi orang pribadi, warisan yang belum terbagi sebagai satu kesatuan, badan, dan bentuk usaha tetap.

Badan sebagai subjek pajak adalah suatu bentuk usaha atau bentuk non-usaha yang meliputi perseroan terbatas, perseroan komanditer, badan usaha milik negara (BUMN) atau badan usaha milik daerah (BUMD), persekutuan atau perkumpulan lainnya, firma, kongsi, perkumpulan koperasi, yayasan, lembaga, dana pensiun, bentuk usaha tetap, dan bentuk usaha lainnya (Suandy, 2011). PPh untuk Wajib Pajak (WP) Badan dihitung dengan mengalikan tarif dan Penghasilan Kena Pajak (PKP) yang kemudian diakui sebagai beban. Oleh karena itu, untuk menghasilkan laba yang optimal, perusahaan cenderung melakukan penghematan pajak.

\section{Tax Avoidance}

Menurut Suandy (2011), upaya dalam melakukan penghematan pajak dapat dilakukan dengan berbagai cara, baik yang masih lawful dikenal dengan istilah tax avoidance, sedangkan yang unlawful dikenal dengan istilah tax evasion (penggelapan pajak). Tax avoidance didefinisikan sebagai pengaturan transaksi dalam rangka memperoleh keuntungan, manfaat, atau pengurangan pajak dengan cara yang unintended (tidak diinginkan) oleh peraturan perpajakan (Brown, 2012). Secara hukum, penghematan pajak dengan cara ini memang tidak dilarang namun sering mendapat sorotan yang kurang baik dari kantor pajak karena dianggap berkonotasi negatif dan menunjukkan perilaku ketidakpatuhan.

Meskipun tax avoidance sering didefinisikan sebagai upaya penghematan yang lawful (berbeda dengan tax evasion yang unlawful), tax avoidance yang dimaksud dalam penelitian ini tidak memisahkan kedua hal tersebut. Hal ini karena menurut Hanlon dan Heitzman (2010), sebagian besar perilaku penghematan tersebut seringkali terkait dengan transaksi yang secara teknis legal dan legalitas transaksi tax avoidance ditentukan setelah adanya fakta, yaitu hasil pemeriksaan oleh fiskus ataupun surat ketetapan pajak (SKP). Oleh karena itu, dapat disimpulkan bahwa tax avoidance meliputi certain tax position (posisi perpajakan yang pasti) dan uncertain tax position (posisi perpajakan yang tidak pasti) yang bisa atau tidak bisa dipertanyakan legalitasnya, bahkan dinyatakan ilegal. 
Penelitian Terdahulu

Tabel 1

Penelitian Terdahulu

\begin{tabular}{|c|c|c|c|}
\hline Peneliti & Variabel & Sampel & Hasil \\
\hline $\begin{array}{l}\text { Masri dan } \\
\text { Martani } \\
(2012)\end{array}$ & $\begin{array}{l}\text { 1. Cost of debt }(\mathrm{Y}) \\
\text { 2. Tax avoidance } \\
(\mathrm{X}) \\
\text { 3. Perubahan tarif } \\
\text { pajak }\left(\mathrm{Z}_{1}\right) \\
\text { 4. Struktur } \\
\text { kepemilikan } \\
\text { keluarga }\left(\mathrm{Z}_{2}\right)\end{array}$ & $\begin{array}{l}255 \text { sampel dari } \\
\text { perusahaan } \\
\text { manufaktur yang } \\
\text { terdaftar di BEI } \\
\text { periode 2008-2010 }\end{array}$ & $\begin{array}{l}\text { 1. Tax avoidance berpengaruh } \\
\text { positif terhadap cost of debt. } \\
\text { 2. Perubahan tarif pajak } \\
\text { berpengaruh negatif terhadap } \\
\text { hubungan tax avoidance } \\
\text { terhadap cost of debt. } \\
\text { 3. Struktur kepemilikan keluarga } \\
\text { berpengaruh positif terhadap } \\
\text { hubungan tax avoidance } \\
\text { terhadap cost of debt. }\end{array}$ \\
\hline $\begin{array}{l}\text { Marcelliana } \\
\text { (2014) }\end{array}$ & $\begin{array}{l}\text { 1. Cost of debt }(\mathrm{Y}) \\
\text { 2. Tax avoidance } \\
\text { (X) }\end{array}$ & $\begin{array}{l}57 \text { perusahaan } \\
\text { manufaktur yang } \\
\text { terdaftar di BEI } \\
\text { selama periode } \\
2010-2012 \\
\end{array}$ & $\begin{array}{l}\text { Tax avoidance berpengaruh } \\
\text { positif terhadap cost of debt. }\end{array}$ \\
\hline $\begin{array}{l}\text { Erniawati } \\
\text { (2014) }\end{array}$ & $\begin{array}{l}\text { 1. Biaya utang (Y) } \\
\text { 2. Tax avoidance } \\
\text { (X) } \\
\text { 3. Kepemilikan } \\
\text { institusional }(\mathrm{Z})\end{array}$ & $\begin{array}{l}210 \text { sampel dari } \\
\text { perusahaan } \\
\text { manufaktur yang } \\
\text { terdaftar di BEI } \\
\text { selama periode } \\
\text { 2010-2012 }\end{array}$ & $\begin{array}{l}\text { 1. Tax avoidance berpengaruh } \\
\text { negatif terhadap cost of debt. } \\
\text { 2. Kepemilikan institusional yang } \\
\text { memenuhi syarat hubungan } \\
\text { istimewa tidak memperkuat } \\
\text { pengaruh tax avoidance } \\
\text { terhadap cost of debt. } \\
\text { 3. Tidak terdapat perbedaan } \\
\text { signifikan antara tax avoidance } \\
\text { yang dilakukan oleh } \\
\text { kepemilikan institusional yang } \\
\text { memenuhi syarat hubungan } \\
\text { istimewa dengan yang tidak. }\end{array}$ \\
\hline $\begin{array}{l}\text { Novianti } \\
\text { (2014) }\end{array}$ & $\begin{array}{l}\text { 1. Cost of debt }(\mathrm{Y}) \\
\text { 2. Tax avoidance } \\
\text { (X) }\end{array}$ & $\begin{array}{l}48 \text { perusahaan } \\
\text { manufaktur yang } \\
\text { terdaftar di BEI } \\
\text { periode } 2010-2012 \text {. }\end{array}$ & $\begin{array}{l}\text { Tax avoidance tidak } \\
\text { berpengaruh positif terhadap } \\
\text { cost of debt. }\end{array}$ \\
\hline $\begin{array}{l}\text { Rahmawati } \\
\text { (2015) }\end{array}$ & $\begin{array}{l}\text { 1. Cost of debt }(\mathrm{Y}) \\
\text { 2. Tax avoidance } \\
\left(\mathrm{X}_{1}\right) \\
\text { 3. Proposi komisaris } \\
\text { independen }\left(\mathrm{X}_{2}\right) \\
\text { 4. Kepemilikan } \\
\text { manajerial }\left(\mathrm{X}_{3}\right) \\
\text { 5. Kepemilikan } \\
\text { institusional }\left(\mathrm{X}_{4}\right) \\
\text { 6. Proporsi komite } \\
\text { audit }\left(\mathrm{X}_{5}\right)\end{array}$ & $\begin{array}{l}40 \text { perusahaan yang } \\
\text { terdaftar di BEI } \\
\text { selama periode } \\
\text { 2009-2013 }\end{array}$ & $\begin{array}{l}\text { 1. Tax avoidance tidak } \\
\text { berpengaruh negatif terhadap } \\
\text { cost of debt. } \\
\text { 2. Proporsi komisaris independen } \\
\text { tidak berpengaruh negatif } \\
\text { terhadap cost of debt. } \\
\text { 3. Kepemilikan manajerial tidak } \\
\text { berpengaruh negatif terhadap } \\
\text { cost of debt. } \\
\text { 4. Kepemilikan institusional tidak } \\
\text { berpengaruh negatif terhadap } \\
\text { cost of debt. } \\
\text { 5. Proporsi komite audit }\end{array}$ \\
\hline
\end{tabular}




\begin{tabular}{|l|l|l|l|}
\hline Peneliti & Variabel & Sampel & \multicolumn{1}{c|}{ Hasil } \\
\hline & & & $\begin{array}{l}\text { berpengaruh negatif terhadap } \\
\text { cost of debt. }\end{array}$ \\
\hline
\end{tabular}

Sumber: Penelitian Terdahulu

\section{Pengembangan Hipotesis}

Menurut penelitian yang dilakukan oleh Erniawati (2014), tax avoidance berpengaruh negatif terhadap cost of debt, sedangkan penelitian Novianti (2014) menyatakan bahwa tax avoidance tidak berpengaruh positif terhadap cost of debt. Berbeda dengan penelitian Erniawati (2014), penelitian Rahmawati (2015) tidak berhasil membuktikan bahwa tax avoidance berpengaruh negatif terhadap cost of debt. Selain itu, dari persamaan regresinya dapat dilihat bahwa koefisien untuk variabel tax avoidance bernilai positif, sehingga dapat disimpulkan bahwa semakin besar tingkat tax avoidance yang dilakukan oleh perusahaan, semakin besar pula cost of debt yang harus ditanggungnya. Hasil penelitian Rahmawati (2015) sejalan dengan penelitian Masri dan Martani (2012) yang juga menyimpulkan bahwa tax avoidance berpengaruh positif terhadap cost of debt. Menurut Masri dan Martani (2012), dengan pemerintah mengeluarkan UU nomor 28 tahun 2007 tentang KUP, melakukan reformasi perpajakan, dan meningkatkan pemberantasan korupsi, kreditor menilai tax avoidance sebagai tindakan yang berisiko sehingga membebankan bunga yang lebih besar. Penelitian Masri dan Martani (2012) tersebut diuji kembali oleh Marcelliana (2014) dan hasilnya menunjukkan bahwa tax avoidance berpengaruh positif terhadap cost of debt.

Ketika memberikan utang, kreditor akan mendapatkan imbal hasil (return) berupa bunga yang merupakan cost of debt bagi perusahaan dan menanggung risiko. Return dan risiko merupakan trade-off. Semakin besar kreditor menilai risiko yang dimiliki suatu perusahaan, semakin besar pula bunga yang akan dibebankan kreditor pada perusahaan tersebut. Ini berarti cost of debt yang ditanggung perusahaan dipengaruhi oleh penilaian kreditor mengenai risiko perusahaan itu. Risiko perusahaan dipengaruhi oleh karakteristik perusahaan dan cara manajemen mengelola perusahaan. Pengelolaan perusahaan untuk memperoleh laba maksimal dapat dikaitkan dengan cara mengelola beban pajak agar berada pada titik minimal dan sesuai dengan peraturan perpajakan yang dikenal dengan istilah tax avoidance. Berdasarkan uraian tersebut, hipotesis penelitian ini dirumuskan sebagai berikut:

Ha : Tax avoidance memiliki pengaruh secara positif terhadap cost of debt pada perusahaan manufaktur yang terdaftar di BEI selama periode 2010-2014.

\section{METODOLOGI PENELITIAN}

\section{Jenis Penelitian}

Jenis penelitian ini adalah penelitian empiris dengan melakukan analisis pada perusahaan manufaktur yang terdaftar di BEI selama periode 2010-2014.

\section{Objek, Populasi, dan Sampel Penelitian}

Objek penelitian ini adalah perusahaan manufaktur yang terdaftar di BEI dengan populasinya perusahaan manufaktur yang terdaftar di BEI selama periode 2010-2014. Sampel dipilih menggunakan purposive sampling dengan kriteria:

1. Perusahaan manufaktur terdaftar di BEI periode 2010-2014.

2. Perusahaan tidak listing dan delisting selama periode 2010-2014. 
3. Perusahaan tidak melakukan kegiatan merger dan akuisisi, dan tidak melakukan perubahan yang drastis terhadap kegiatan utamanya selama periode 2010-2014.

4. Perusahaan melaporkan keuangan yang diaudit.

5. Perusahaan mempublikasikan laporan keuangannya dengan menggunakan tahun buku keuangan yang dimulai pada 1 Januari sampai 31 Desember.

6. Perusahaan melaporkan laba yang positif

7. Perusahaan memiliki beban bunga dan beban pajak kini.

\section{Variabel Penelitian}

Terdapat dua variabel yang akan diteliti dalam penelitian ini, yaitu tax avoidance yang diukur dengan ETR sebagai variabel independen dan cost of debt sebagai variabel dependen.

\section{Operasionalisasi Variabel}

\section{Tabel 2}

Operasionalisasi Variabel

\begin{tabular}{|c|c|c|c|}
\hline Variabel & Konsep & Dimensi & Skala \\
\hline $\begin{array}{c}\text { Cost of } \\
\text { Debt (Y) }\end{array}$ & $\begin{array}{l}\text { Cost of debt }(\mathrm{Y}) \text { merupakan } \\
\text { tingkat pengembalian yang } \\
\text { diinginkan kreditor saat } \\
\text { memberikan pendanaan kepada } \\
\text { perusahaan (Fabozzi dalam Masri } \\
\text { dan Martani, 2012). }\end{array}$ & $\begin{array}{l}\text { Menurut Pittman dan Fortin dalam } \\
\text { Masri dan Martani (2012), cost of } \\
\text { debt dapat diukur dengan: } \\
\text { beban bunga } \\
\text { rata - rata pinjaman } \\
\text { jangka panjang dan pendek } \\
\text { yang berbunga }\end{array}$ & Rasio \\
\hline $\begin{array}{c}\text { Tax } \\
\text { avoidance } \\
\text { (X) }\end{array}$ & $\begin{array}{l}\text { Tax avoidance merupakan } \\
\text { pengaturan transaksi dalam rangka } \\
\text { memperoleh keuntungan, manfaat, } \\
\text { atau pengurangan pajak dengan } \\
\text { cara yang tidak diinginkan } \\
\text { (unintended) oleh peraturan } \\
\text { perpajakan (Brown, 2012). }\end{array}$ & $\begin{array}{l}\text { Salah satu cara pengukuran tax } \\
\text { avoidance menurut Hanlon dan } \\
\text { Heitzman (2010) yaitu current } \\
\text { ETR dengan: } \\
\qquad \frac{\text { beban pajak kini }}{\text { laba sebelum pajak }}\end{array}$ & Rasio \\
\hline
\end{tabular}

\section{Sumber: Penelitian Terdahulu}

\section{Model Penelitian}

Model penelitian digambarkan sebagai berikut:

\begin{tabular}{|c|c|c|}
\hline Tax Avoidance (X) & 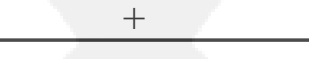 & Cost of Debt $(\mathbf{Y})$ \\
\hline
\end{tabular}

\section{Gambar 1}

\section{Model Penelitian \\ Sumber: Penelitian Terdahulu}

\section{Jenis dan Teknik Pengumpulan Data}

Jenis data yang digunakan dalam penelitian ini adalah data arsip sekunder yang dikumpulkan dengan menggunakan teknik pengumpulan data di basis data. Data yang digunakan dalam penelitian ini diperoleh dari:

1. Indonesian Capital Market Directory (ICMD) untuk memperoleh daftar nama perusahaan manufaktur yang terdaftar di BEI selama periode tahun 2010-2014.

2. www.idx.co.id untuk memperoleh data laporan keuangan dan laporan tahunan perusahaan manufaktur yang diperlukan. 


\section{Uji Pendahuluan}

\section{ANALISIS DAN PEMBAHASAN HASIL}

\section{Statistik Deskriptif}

Statistik deskriptif, menurut Ghozali (2011), memberikan gambaran atau deskripsi suatu data. Deskripsi data pada penelitian ini dilihat dari nilai rata-rata, maksimum, minimum, dan standar deviasi satu variabel dependen, yaitu cost of debt dan satu variabel independen, yaitu tax avoidance yang diukur dengan ETR. Statistik deskriptif tersebut dapat dilihat dalam tabel 3 berikut ini.

Tabel 3

Statistik Deskriptif

Descriptive Statistics

\begin{tabular}{|l|c|r|r|c|r|}
\hline & $\mathrm{N}$ & Minimum & Maximum & Mean & \multicolumn{1}{c|}{ Std. Deviation } \\
\hline ETR & 245 & 0,0779 & 0,9611 & 0,2781 & 0,1190 \\
CoD & 245 & 0,0017 & 0,1329 & 0,0351 & 0,0259 \\
Valid N (listwise) & 245 & & & & \\
\hline
\end{tabular}

Sumber: Data Diolah

Tabel 3 menunjukkan bahwa terdapat 245 data yang diobservasi (N) untuk masingmasing variabel. Data tersebut diperoleh dari 49 perusahaan manufaktur yang terdaftar di BEI dengan periode pengamatan 5 tahun.

Pada variabel tax avoidance yang diukur dengan menggunakan ETR, nilai ETR minimum adalah sebesar 0,0779 pada Kedaung Indah Can Tbk tahun 2010 yang mengindikasikan tingginya tax avoidance, sedangkan nilai ETR maksimum adalah sebesar 0,9611 pada Nusantara Inti Corpora Tbk tahun 2014 yang mengindikasikan rendahnya tax avoidance. Tabel tersebut juga menunjukkan nilai rata-rata ETR sebesar 0,2779 dengan standar deviasi sebesar 0,1202. Nilai rata-rata ETR tersebut lebih tinggi dari tarif pajak badan yaitu $25 \%$ bagi perusahaan berbentuk perseroan terbatas yang sahamnya kurang dari $40 \%$ dimiliki publik dan $20 \%$ bagi perusahaan yang sahamnya lebih dari $40 \%$ dimiliki publik yang mengindikasikan bahwa secara rata-rata kemungkinan melakukan tax avoindance rendah pada perusahaan manufaktur yang terdaftar di BEI tahun 2010-2014.

Pada variabel cost of debt yang dinotasikan dengan CoD, nilai minimum adalah sebesar 0,0017 atau 0,17\% dari rata-rata liabilitas pada Indo Kordsa Tbk tahun 2014, sedangkan nilai maksimum adalah 0,1329 atau 13,3\% dari rata-rata liabilitas pada Nusantara Inti Corpora Tbk tahun 2011. Nilai rata-rata cost of debt yang ditunjukkan oleh tabel 4.2 adalah sebesar 0,0351 dengan standar deviasi 0,0259 . Hal tersebut menunjukkan bahwa secara rata-rata perusahaan manufaktur yang terdaftar di BEI tahun 2010-2014 menanggung cost of debt sebesar 3,51\% dari rata-rata liabilitasnya baik liabilitas jangka panjang maupun jangka pendek.

\section{Uji Normalitas}

Dalam model regresi, uji normalitas bertujuan untuk menguji apakah variabel pengganggu atau residual memiliki distribusi normal karena pengujian nilai t dan pengujian nilai F mengasumsikan nilai residual yang memiliki distribusi normal (Ghozali, 2011). Penelitian ini menggunakan Kolmogorov-Smirnov (K-S) Test. Tabel 4 berikut ini menunjukkan hasil K-S Test terhadap nilai residual model regresi tax avoidance (ETR) terhadap cost of debt $(\mathrm{CoD})$. 
Tabel 4

Hasil Uji Normalitas Nilai Residual Model Regresi ETR terhadap CoD dengan

Kolmogorov-Smirnov

One-Sample Kolmogorov-Smirnov Test

\begin{tabular}{|ll|r|}
\hline & & \multicolumn{2}{|c|}{ Unstandardized Residual } \\
\hline $\mathrm{N}$ & & 245 \\
Normal Parameters & Mean &, 0000000 \\
& Std. Deviation & .02510217 \\
Most Extreme & Absolute & .100 \\
Differences & Positive & .100 \\
\multicolumn{2}{|c|}{ Negative } &,- 075 \\
Kolmogorov-Smirnov Z & 1,569 \\
Asymp. Sig. (2-tailed) &, 015 \\
\hline $\begin{array}{l}\text { a. Test distribution is Normal. } \\
\text { b. Calculated from data. }\end{array}$ \\
\hline
\end{tabular}

Sumber: Data Diolah

Nilai residual dikatakan mengikuti distribusi normal jika probabilitas signifikansi uji K-S $>0,05$. Tabel 4 tersebut menunjukkan nilai K-S untuk residual model regresi tersebut adalah 1,569 dengan probabilitas signifikansi $0.015<0.05$ yang berarti nilai residual tersebut tidak mengikuti distribusi normal. Data yang tidak terdistribusi secara normal dapat ditransformasi agar menjadi normal (Ghozali, 2011). Dua kali proses transformasi dilakukan pada data cost of debt. Tranformasi pertama dilakukan dengan rumus $\log (\mathrm{x})$. Hasilnya kemudian ditransformasi lagi menggunakan rumus $\log (\mathrm{k}-\mathrm{x})$ dengan $\mathrm{k}$ ialah nilai maksimum. Tabel 5 berikut ini menunjukkan hasil K-S Test pada nilai residual model regresi tax avoidance (ETR) terhadap data cost of debt hasil transformasi kedua (CoDt2).

Tabel 5

Hasil Uji Normalitas Nilai Residual Model Regresi ETR terhadap CoDt2 dengan Kolmogorov-Smirnov

One-Sample Kolmogorov-Smirnov Test

\begin{tabular}{|ll|r|}
\hline & & Unstandardized Residual \\
\hline $\mathrm{N}$ & 244 \\
Normal Parameters & Mean & .0000000 \\
& Std. Deviation & .26835751 \\
Most Extreme & Absolute & .060 \\
Differences & Positive & .033 \\
Kolmogorov-Smirnov Z & Negative & -.060 \\
Asymp. Sig. (2-tailed) & .932 \\
\hline $\begin{array}{l}\text { a. Test distribution is Normal. } \\
\text { b. Calculated from data. }\end{array}$ \\
\hline
\end{tabular}

\section{Sumber: Data Diolah}

Pada tabel 5 tersebut, dapat dilihat bahwa jumlah data yang diobservasi $(\mathrm{N})$ menjadi sebesar 244. Hal ini disebabkan karena bentuk transformasi $\log 10(\mathrm{k}-\mathrm{x})$ juga secara langsung mengeliminasi outliner dari data yang diobservasi. Nilai K-S untuk nilai residual model regresi tersebut adalah 0,932 dengan probabilitas signifikansi $0.350>0.05$ yang berarti nilai residual tersebut terdistribusi normal. 


\section{Uji Hipotesis}

\section{Pengujian Nilai t}

Pengujian nilai t menunjukkan seberapa jauh pengaruh satu variabel independen secara individual menerangkan variabel dependen (Ghozali, 2011). Variabel independen dikatakan memengaruhi variabel dependen apabila t-hitung kurang dari t-tabel atau nilai probabilitas signifikansi kurang dari nilai alpha $(\alpha)$. Hasil pengujian nilai $t$ dapat dilihat dalam tabel 6 berikut ini.

\section{Tabel 6}

Hasil Pengujian Nilai t

\begin{tabular}{|c|c|c|c|c|c|c|}
\hline \multirow{2}{*}{\multicolumn{2}{|c|}{ Model }} & \multicolumn{2}{|c|}{$\begin{array}{c}\text { Unstandardized } \\
\text { Coefficients }\end{array}$} & $\begin{array}{l}\text { Standardized } \\
\text { Coefficients }\end{array}$ & \multirow[t]{2}{*}{$\bar{T}$} & \multirow[t]{2}{*}{ Sig. } \\
\hline & & B & Std. Error & Beta & & \\
\hline 1 & $\begin{array}{l}\text { (Constant) } \\
\text { ETR }\end{array}$ & $\begin{array}{l}-.027 \\
-.684\end{array}$ & $\begin{array}{l}.044 \\
.145\end{array}$ & -.291 & $\begin{array}{r}-.625 \\
-4.727\end{array}$ & $\begin{array}{l}.533 \\
.000\end{array}$ \\
\hline
\end{tabular}

\section{Sumber: Data Diolah}

Berdasarkan tabel 6 tersebut, persamaan regresi dalam penelitian ini adalah sebagai berikut:

$$
Y=-0,027-0,684 X
$$

Keterangan:

$\mathrm{Y}=$ cost of debt

$\mathrm{X}=\mathrm{ETR}$

Selain persamaan regresi, tabel 6 tersebut juga menunjukkan nilai t hitung sebesar -4,727 dengan nilai probabilitas signifikansi 0,000. Nilai probabilitas signifikansi tersebut lebih kecil dibandingkan dengan nilai alpha $(\alpha)$ yaitu $10 \%$ atau 0,1 yang berarti Ha diterima. Oleh karena itu, dapat disimpulkan bahwa ETR berpengaruh negatif-tax avoidance berpengaruh positif - terhadap cost of debt pada perusahaan manufaktur yang terdaftar di BEI selama periode 2010-2014.

\section{Pengujian Nilai F}

Pengujian nilai F (Goodness of Fit Test) menunjukkan uji kesesuaian model (Ghozali, 2011) atau apakah suatu model penelitian baik dalam menerangkan variasi variabel dependennya. Suatu persamaan regresi memenuhi kriteria Goodness of Fit apabila nilai F hitung lebih besar dibandingkan dengan $\mathrm{F}$ tabel atau nilai probabilitas signifikansi kurang dari nilai alpha $(\alpha)$. Hasil pengujian nilai $\mathrm{F}$ dapat dilihat pada tabel 7 berikut ini.

Tabel 7

\section{Hasil Pengujian Nilai F}

ANOVA $^{\mathrm{a}}$

\begin{tabular}{|c|c|c|c|c|c|c|}
\hline & Model & Sum of Squares & $\overline{\mathrm{Df}}$ & Mean Square & $\mathrm{F}$ & Sig. \\
\hline \multirow{3}{*}{1} & Regression & 1.616 & 1 & \multirow{3}{*}{$\begin{array}{r}1.616 \\
.072\end{array}$} & \multirow[t]{3}{*}{22.346} & \multirow[t]{3}{*}{$.000^{\mathrm{b}}$} \\
\hline & Residual & 17.500 & 242 & & & \\
\hline & Total & 19.116 & 243 & & & \\
\hline
\end{tabular}

\section{Sumber: Data Diolah}


Tabel 7 menunjukkan bahwa nilai $\mathrm{F}$ hitung dalam penelitian ini adalah sebesar 22,346 dengan nilai probabilitas signifikansi 0,000 . Nilai probabilitas signifikansi tersebut kurang dari nilai alpha $(\alpha)$, yaitu $10 \%$ atau 0,1 yang berarti Ha diterima. Maka, dapat disimpulkan bahwa persamaan regresi dalam penelitian ini dinyatakan baik dalam menerangkan variasi variabel dependennya/memenuhi syarat Goodness of Fit.

\section{Koefisien Determinasi}

Koefisien determinasi $\left(\mathrm{R}^{2}\right)$ pada intinya mengukur seberapa jauh kemampuan model dalam menerangkan variasi variabel dependen (Ghozali, 2011). Hasil uji koefisien determinasi ditunjukkan dengan tabel 8 , sebagai berikut:

\section{Tabel 8}

Hasil Uji Koefisien Determinasi Model Summaryb

\begin{tabular}{|l|c|r|r|r|}
\hline Model & $\mathrm{R}$ & $\mathrm{R}$ Square & Adjusted R Square & Std. Error of the Estimate \\
\hline 1 & $.291^{\mathrm{a}}$ & .085 & .081 & .26891 \\
\hline
\end{tabular}

\section{Sumber: Data Diolah}

Koefisien determinasi menggambarkan seberapa besar variasi variabel dependen yang diteliti, yaitu cost of debt dapat dijelaskan oleh variasi variabel independennya, yaitu tax avoidance yang diukur dengan ETR. Tabel 8 tersebut menunjukkan bahwa nilai $\mathrm{R}^{2}$ adalah sebesar 0,085 yang berarti 8,5\% variasi variabel cost of debt dapat dijelaskan oleh ETR dan sisanya, yaitu 0,915 atau 91,5\% dijelaskan oleh variabel lain yang tidak diteliti dalam penelitian ini.

\section{Analisis Hasil Penelitian}

Penelitian ini bertujuan untuk menguji kembali pengaruh tax avoidance terhadap cost of debt pada perusahaan manufaktur yang terdaftar di BEI tahun 2010-2014. Tax avoidance sebagai variabel independen diukur dengan menggunakan ETR. ETR memiliki hubungan terbalik dengan tax avoidance sehingga semakin tinggi nilai ETR mengindikasikan semakin rendahnya tax avoidance yang dilakukan oleh suatu perusahaan begitupun sebaliknya, semakin rendah nilai ETR mengindikasikan semakin tingginya tax avoidance yang dilakukan oleh suatu perusahaan.

Tabel 5 menunjukkan bahwa ETR memiliki koefisien -0,684 dengan nilai probabilitas signifikansi 0,000 yang berarti ETR memiliki pengaruh negatif signifikan terhadap cost of debt. Karena ETR memiliki hubungan terbalik dengan tax avoidance, hasil tersebut sekaligus menunjukkan bahwa tax avoidance memiliki pengaruh positif signifikan terhadap cost of debt. Semakin tinggi tax avoidance yang dilakukan suatu perusahaan-ditunjukkan dengan ETR yang rendah, semakin tinggi cost of debt yang harus ditanggung perusahaan tersebut. Sebaliknya, semakin rendah tax avoidance yang dilakukan suatu perusahaan-ditunjukkan dengan ETR yang tinggi, semakin rendah cost of debt yang harus ditanggung perusahaan tersebut.

Hasil penelitian ini mendukung penelitian yang dilakukan Masri dan Martani (2012) dan Marcelliana (2014) yang mengatakan bahwa tax avoidance berpengaruh positif terhadap cost of debt. Dengan pemerintah mengeluarkan UU nomor 28 tahun 2007 (sekarang UU nomor 16 
tahun 2009) tentang Ketentuan Umum dan Tata Cara Perpajakan, melakukan reformasi perpajakan, dan meningkatkan pemberantasan korupsi, kreditor menilai perilaku tax avoidance sebagai tindakan yang mengandung risiko (Masri dan Martani, 2012). Dengan mempertimbangkan perilaku tax avoidance sebagai risiko, kreditor akan membebankan bunga yang lebih besar sehingga cost of debt yang ditanggung perusahaan juga menjadi semakin tinggi.

\section{PENUTUP}

\section{Kesimpulan}

Penelitian ini bertujuan untuk menguji kembali pengaruh tax avoidance terhadap cost of debt pada perusahaan manufaktur yang terdaftar di BEI selama periode tahun 2010-2014. Tax avoidance sebagai variabel independen diukur menggunakan current ETR dengan rumus beban pajak kini dibagi laba sebelum pajak, sedangkan cost of debt sebagai variabel dependen diukur dengan membagi biaya bunga tahun berjalan dengan rata-rata liabilitas jangka panjang dan pendek.

Penelitian ini menguji sampel sebanyak 49 perusahaan manufaktur terdaftar di BEI selama periode 2010-2014 yang dipilih dengan menggunakan purposive sampling. Berdasarkan analisis yang telah dilakukan, diperoleh hasil bahwa ETR sebagai proksi tax avoidance memiliki pengaruh negatif signifikan terhadap cost of debt sehingga dapat disimpulkan bahwa tax avoidance memiliki pengaruh positif signifikan terhadap cost of debt.

Hasil penelitian ini mendukung penelitian yang dilakukan Masri dan Martani (2012) dan Marcelliana (2014) yang menyimpulkan bahwa tax avoidance berpengaruh positif terhadap cost of debt. Dengan pemerintah mengeluarkan UU nomor 28 tahun 2007 (sekarang UU nomor 16 tahun 2009) tentang Ketentuan Umum dan Tata Cara Perpajakan, melakukan reformasi perpajakan, dan meningkatkan pemberantasan korupsi, kreditor menilai perilaku tax avoidance sebagai tindakan yang mengandung risiko (Masri dan Martani, 2012). Pertimbangan perilaku tax avoidance sebagai risiko ini akan membuat kreditor cenderung membebankan bunga yang lebih besar sehingga cost of debt yang ditanggung perusahaan juga menjadi semakin tinggi. Dengan demikian, tujuan penelitian ini tercapai.

\section{Keterbatasan}

Penelitian ini tidak terlepas dari keterbatasan yang mungkin dapat menimbulkan gangguan terhadap hasil penelitian. Keterbatasan tersebut ialah antara lain:

1. Menurut Pittman dan Fortin dalam Masri dan Martani (2012), cost of debt diukur dengan rumus beban bunga yang dibayarkan oleh perusahaan dalam periode satu tahun dibagi rata-rata pinjaman jangka panjang dan jangka pendek yang berbunga. Akan tetapi, dalam laporan keuangan yang dipublikasikan tidak ditemukan informasi liabilitas jangka panjang dan jangka pendek yang berbunga terpisah dari yang tidak berbunga sehingga penelitian ini menggunakan rata-rata dari keseluruhan liabilitas jangka panjang dan jangka pendek. Keterbatasan ini mengakibatkan pengukuran nilai cost of debt yang kurang akurat sehingga mungkin menimbulkan hasil yang bias.

2. Sampel hanya terbatas pada perusahaan manufaktur terdaftar di BEI. Sampel dipilih atas pertimbangan tersedianya data cross section dengan kesamaan karakteristik 
dalam jumlah yang cukup banyak. Akan tetapi, pemilihan sampel ini mengakibatkan hasil penelitian tidak dapat digeneralisir untuk jenis industri selain manufaktur.

\section{Saran}

Untuk mengatasi keterbatasan dalam penelitian ini, penelitian selanjutnya diharapkan:

1. Mempertimbangkan penggunaan data arsip primer yang dikumpulkan dengan teknik analisis data sehingga diperoleh informasi mengenai liabilitas jangka panjang dan jangka pendek yang berbunga terpisah dari yang tidak berbunga dan cost of debt dapat diukur secara lebih tepat.

2. Mempertimbangkan sampel yang lebih luas (tidak terbatas pada perusahaan manufaktur saja) sehingga hasil penelitian dapat digeneralisir untuk semua jenis industri.

\section{DAFTAR PUSTAKA}

Brown, Karen B. (2012). A Comparative Look at Regulation of Corporate Tax Avoidance. New York: Springer.

Butarbutar, Nurlina. (2011). Faktor-Faktor yang Mempengaruhi Tingkat Pengungkapan Laporan Keuangan Pada Perusahaan Manufaktur yang Tercatat di BEI periode 2008-2010. Skripsi. Universitas Sumatera Utara, Medan.

Erniawati, Ika. (2014). Analisis Pengaruh Tax Avoidance terhadap Biaya Utang dan Kepemilikan Institusional. Published Skripsi. Universitas Muhamadiyah Surakarta, Surakarta.

Ghozali, Imam. (2011). Analisis Multivariate Dengan Program SPSS (Cetakan Kelima). Semarang: Badan Penerbit Universitas Diponegoro.

Hanlon, Michelle dan Shane Heitzman. (2010). A Review of Tax Research. Journal of Accounting and Economics. No. 50, Hal. 127-178

Hartono, Jogiyanto. (2010). Metodologi Penelitian Bisnis (Salah Kaprah dan Pengalamanpengalaman). Yogyakarta: BPFE.

(2013). Metodologi Penelitian Bisnis (Salah Kaprah dan Pengalamanpengalaman). Yogyakarta: BPFE.

(2014). Teori Portofolio dan Analisis Investasi (Edisi 9). Yogyakarta:

BPFE.

Jogiyanto. (2007). Metodologi Penelitian Bisnis (Salah Kaprah dan Pengalamanpengalaman). Yogyakarta: BPFE.

Marcelliana, Elsa. (2014). Pengaruh Tax Avoidance terhadap Cost of Debt pada Perusahaan Manufaktur yang Terdaftar di Bursa Efek Indonesia Periode 2010-2012. Skripsi. Universitas Atma Jaya Yogyakarta, Yogyakarta. 
Masri, Indah dan Dwi Martani. (2012). Pengaruh Tax Avoidance terhadap Cost of Debt. Simposium Nasional Akuntansi XV. Universitas Indonesia, Depok.

Muwardi, Nanang Arif. (2010). Pengaruh Kandungan Informasi Laporan Keuangan terhadap Abnormal Return Saham pada Perusahaan yang Termasuk dalam Jakarta Islamic Indexs (JII) tahun 2004-2007. Skripsi. UIN Sunan Kalijaga, Yogyakarta.

Novianti, Arti Resha. (2014). Pengaruh Penghindaran Pajak terhadap Biaya Hutang (Studi Kasus pada Perusahaan Manufaktur yang Terdaftar di Bursa Efek Indonesia pada tahun 2010-2012). Published Skripsi. Universitas Pendidikan Indonesia, Bandung.

Peraturan Pemerintah Nomor 46 Tahun 2013 tentang Pajak Penghasilan atas Penghasilan dari Usaha yang Diterima atau Diperoleh Wajib Pajak yang Memiliki Peredaran Bruto Tertentu.

Peraturan Pemerintah Nomor 56 Tahun 2015 tentang Penurunan Tarif Pajak Penghasilan bagi Wajib Pajak Badan Dalam Negeri yang Berbentuk Perseroan Terbuka.

Rahmawati. (2015). Pengaruh Penghindaran Pajak dan Good Corporate Governance terhadap Biaya Utang. Published Skripsi. Universitas Negeri Padang, Padang.

Suandy, Erly. (2011). Hukum Pajak (Edisi 5). Jakarta: Salemba Empat. (2011). Perencanaan Pajak (Edisi 5). Jakarta: Salemba Empat.

Undang-undang Nomor 36 Tahun 2008 tentang Pajak Penghasilan. 